\title{
Characterization of Nuclear Microsatellite Markers for the Narrow Endemic Syringa josikaea Jacq. fil. ex Rchb.
}

\author{
Bertalan LENDVAY',2, Andrzej PEDRYC ${ }^{1}$, Mária HÖHN* \\ ${ }^{1}$ Corvinus University of Budapest, Faculty of Horticultural Science, 44 Ménesi út, Budapest, \\ H-1118, Hungary; maria.hohn@uni-corvinus.hu ( ${ }^{*}$ corresponding author) \\ ${ }^{2}$ Swiss Federal Research Institute WSL, Biodiversity and Conservation Biology Research \\ Unit, 111 Zürcherstrasse, Birmensdorf CH-8903 Switzerland
}

\begin{abstract}
The species of the genus Syringa L. are among the most popular ornamental plants worldwide. One particular species, Syringa josikaea, a rare endemic of the Carpathian Mountains, is of great conservation interest. Although microsatellite markers may be useful for studying the genetic variability of varieties and populations, no microsatellites have previously been characterized for any species of the Syringa genus. Our aim was therefore to test the applicability of microsatellite primers developed for neighboring genera (Olea and Ligustrum) and to complement these with markers isolated and characterized for S. josikaea. Twelve primer pairs of Olea and Ligustrum were tested by optimizing PCR conditions and checking the variability in 40 samples of two populations of $S$. josikaea. Two of them proved to be easy to PCR amplify and variable at the same time. To develop new primers we constructed a microsatellite enriched library and sequenced 48 clones. 18 sequences contained microsatellite motifs, and three of the designed primer pairs presented high allele variability. The five primer pairs characterized for $S$. josikaea proved to be highly informative and sufficient to distinguish between individuals. These microsatellite primers are valuable tools to study genetic variation of native populations, genetic lineages of hybrids and cultivars of $S$. josikaea.
\end{abstract}

Keywords: genetic variability, lilac, microsatellite development, molecular marker, plant breeding, population genetics

\section{Introduction}

Syringa L. species are among the most popular ornamental plants. New varieties keep being bred with the aim of producing types with new flower properties, extended blossoming time and better pathogen resistance (Fiala, 2008). Breeders could benefit from the results of genetic studies, however, in the case of Syringa species we are aware of only a few surveys exploring genetic characteristics of germplasm collections or populations. These mainly rely on dominant RAPDs (Kochieva et al., 2004; Marsolais et al., 1993; Melnikova et al., 2009; Xinlu et al., 1999) or ISSRs (Rzepka-Plevneš et al., 2006), while codominant allozyme variability was examined only in one case (HuiRong et al., 2009).

The majority of the nearly 25 Syringa species occur in Asia while only two species are native to Europe. One of the two European Syringa species, Syringa josikaea Jacq. fil. ex Rchb., besides its importance in horticulture (Fiala 2008), is of great conservation significance. S. josikaea is an endangered narrow endemic shrub of the Eastern Carpathians found exclusively in the Ukrainian Carpathians and Romanian Apuseni Mountains (Dihoru and Negrean, 2009). Its few remnant populations occur as small patches in creek valleys - in many cases comprising only a few individuals -, divided by large distances from the nearest population (Lendvay et al., in press). Thus, revealing the in-depth genetic structure of $S$. josikaea should add important aspects to the science-based conservation management of the species.

Nuclear microsatellite markers can be useful tools in genetic studies for both breeding and conservation genetic purposes due to their reproducibility, codominant inheritance and high variability (Frankham et al., 2002; Powell et al., 1996). However, microsatellites have been tested for the Syringa genus in only a single case by de la Rosa et al. (2002) who developed a set of microsatellite primers for Olea europaea L., and reported two of their markers to be amplifiable and variable in their sample of two Syringa vulgaris L. individuals. Among the taxa closely related to Syringa microsatellite primer pairs have been only developed for Ligustrum ovalifolium Hassk. (Kodama et al., 2008). Although cross-species amplification was not tested during the development of the ten markers (M. Maki, personal communication), the L. ovalifolium markers were promising candidates for Syringa because Ligustrum is phylogenetically embedded in this genus (Li et al., 2002, 2012).

Our aim was to test the suitability of $O$. europaea (de la Rosa et al., 2002) and L. ovalifolium (Kodama et al., 2008) microsatellite markers and to optimize and characterize 
302

them for $S$. josikaea. In addition, we intended to complement these markers with de novo developed nuclear microsatellite primers for $S$. josikaea, new to the whole genus Syringa.

\section{Materials and methods}

Transferability of microsatellite primers from the related genera Olea and Ligustrum

We attempted to PCR-amplify DNA of $S$. josikaea using primer pairs that were previously tested on $S$. vulgaris from the $O$. europaea microsatellite marker set of de la Rosa et al. (2002) and from the microsatellite primer pairs developed for L. ovalifolium (Kodoma et al., 2008) (Tab. 1). Genomic DNA samples of $S$. josikaea were extracted with Qiagen DNeasy Plant Mini Kit (Qiagen, Hilden, Germany). We used PCR conditions for each primer pair suggested by the above authors, but in cases when there was no or only weak amplification we optimized the PCR conditions by decreasing annealing temperatures to $45^{\circ} \mathrm{C}$, altering $\mathrm{MgCl}_{2}$ concentrations up to $4 \mathrm{mM}$ final concentration and by the use of different DNA polymerase enzymes including recombinant Taq and DreamTaq (Thermo Scientific, Burlington, Canada) and a new-generation polymerase KAPAHiFi (Kapabiosystems, Boston, MA, USA). Eventually all primer pairs that successfully yielded PCR products were used with the following identical PCR conditions. The PCRs were carried out with the single tube M13-tailed nested PCR technique (Schuelke, 2000), where forward microsatellite primers are extended with a 5' M13(-21)F sequence tail (5'-GTAAAACGACGGCCAGT-3') and 5' 6-FAM fluorescent dye labeled M13(21)F oligonucleotide is added to the reaction to act as a third primer. Thus, instead of labeling several forward primers only a single M13(-21)F oligonucleotide requires fluorescent labeling, making this technique ideal for primer testing. $20 \mu \mathrm{l}$ reaction mixtures contained $1 \times \mathrm{NH}_{4} \mathrm{SO}_{4}$ containing Taq DNA polymerase reaction buffer (Thermo Scientific), $2.5 \mathrm{mM} \mathrm{MgCl}, 0.2 \mathrm{mM}$ dNTPs, $0.25 \mu \mathrm{M}$ forward primer bearing 5 ' M13(-21)F sequence extension, $0.75 \mu \mathrm{M}$ reverse primer, $0.5 \mu \mathrm{M}$ 5' 6-FAM fluorescent dye labeled M13(-21)F primer, 0.5 u recombinant Taq DNA polymerase (Thermo Scientific, Burlington, Canada) and $1.5 \mu \mathrm{l}$ template DNA. PCRs were performed in a PTC 200 thermocycler (MJ Research, Quebec, Canada) starting with $5 \mathrm{~min}$ initial denaturation at $94^{\circ} \mathrm{C}$, followed by 30 cycles of $94^{\circ} \mathrm{C}$ denaturation, $52^{\circ} \mathrm{C}$ annealing, $72^{\circ} \mathrm{C}$ elongation, each step lasting $30 \mathrm{~s}$, and a final extension at $72^{\circ} \mathrm{C}$ for $30 \mathrm{~min}$. The long final extension time was chosen to reduce the length stuttering of the fragments. To test the variability of the amplifiable markers and to characterize them for $S$. josikaea we screened allele lengths of 20-20 accessions originating from two distinct areas with frequent occurrence of the species, i.e. forests near Pidpolozzya, Zakarpattia County, Ukraine and Remeți, Bihor County, Romania. PCR fragments were run on an
ABI 3100 genetic analyzer (Applied Biosystems, Foster City, CA, USA) with a GenScan - 500 ROX internal size standard (Applied Biosystems). Fragment lengths were scored with the software GeneMapper version 3.7 (Applied Biosystems). The overall range of length variability was measured. The number of alleles and the number of genotypes were calculated for each primer pair. Observed and expected heterozygosities, inbreeding coefficient $\left(\mathrm{F}_{\mathrm{IS}}\right)$ and deviation from Hardy-Weinberg-equilibrium based on Markov chain exact test (Guo and Thompson, 1992) with forecasted chain length of $10^{6}$ and dememorization steps of $10^{5}$ were calculated with the Arlequin software 3.5.1.3 (Excoffier and Lischer, 2010) per locus for the Ukrainian and Romanian samples separately.

\section{De novo microsatellite primer development}

High quality and quantity (unfragmented, $>100 \mathrm{ng} / \mu \mathrm{l}$ ) genomic DNA was extracted from fresh bud tissue of an individual from Remeți, Bihor County, Romania using the Qiagen DNeasy Plant Mini Kit (Qiagen). We constructed a microsatellite enriched library based on the method of Bloor et al. (2001) and the FIASCO protocol (Zane et al., 2002), two similar, widely used cost effective technique for the isolation of nuclear microsatellites. As the first step to construct the library, genomic DNA was totally digested with the four-cutter Tru 1I restriction enzyme (TTAA recognition site, Thermo Scientific) following the manufacturers' protocol. As a standard chlorophorm purification the reaction mixture was extracted with chlorophorm, precipitated with isopropanol, the formed pellet was washed with $70 \%$ cold ethanol and resolved in water after air-drying. The digested DNA fragments were ligated in an adequate sticky-end adaptor Top/Bottom 5'-CTCGTAGACTGCGTACC-3'/3'-CATCTCTGACGCATGGATT-5' with T4 DNA ligase (Promega, Madison, WI, USA). PCR amplification was performed with the oligonucleotide "Top" as primer in a $20 \mu \mathrm{l}$ reaction mixture of $1 \mathrm{x}$ $\mathrm{NH}_{4} \mathrm{SO}_{4}$ containing Taq DNA polymerase reaction buffer (Thermo Scientific), $1.2 \mathrm{mM} \mathrm{MgCl}, 0.2 \mathrm{mM}$ dNTPs, $25 \mu \mathrm{g} / \mathrm{ml} \mathrm{BSA}, 1.6 \mu \mathrm{M}$ "Top" primer, $0.5 \mathrm{u}$ recombinant Taq DNA polymerase (Thermo Scientific) and $1.5 \mu \mathrm{l} \mathrm{li}$ gated DNA as template. Thermal cycling conditions were 5 min $94^{\circ} \mathrm{C}$ initial denaturation, followed by 30 cycles of $94^{\circ} \mathrm{C}$ denaturation for $30 \mathrm{~s}, 52^{\circ} \mathrm{C}$ annealing for $30 \mathrm{~s}$, $72^{\circ} \mathrm{C}$ extension for $1 \mathrm{~min}$ and a final extension at $72^{\circ} \mathrm{C}$ for $30 \mathrm{~min}$. To enrich the microsatellite containing fragments $6 \mu \mathrm{l}$ of the PCR product was mixed with $75 \mu \mathrm{mol}$ 5 ' biotin modified $(\mathrm{CT})_{12}$ oligonucleotide in $30 \mu \mathrm{l}$ final volume and the $(\mathrm{CT})_{12}$ was hybridized to the microsatellite regions of the PCR fragments by keeping the mixture at $94^{\circ} \mathrm{C}$ for $7 \mathrm{~min}$ and cooling it down to room temperature with $0.1^{\circ} \mathrm{C} / \mathrm{s}$ ramping speed. The biotin tagged fragments were selected with Streptavidin-coupled magnetic beads (Dynabeads M-280 Streptavidin; Invitrogen, Carlsbad, CA, USA) on a magnet following the manufacturers' protocol with applying a pre-blocking of the beads with 
an indifferent PCR product. After immobilization of the biotin tagged fragments to the Streptavidin coated beads and three times washing steps in 1x Binding and Washing buffer the fragments were resuspended in $100 \mu \mathrm{l}$ water. PCR was made with the resuspended fragments using the "Top" oligonucleotid for primer as described above. For selecting the longer DNA fragments, the whole product was loaded on a $1 \%$ TAE agarose gel, run for $1 \mathrm{~h}$ on $60 \mathrm{~V}$ and ethidium bromide stained. The DNA smear over 200 bp length was excised and purified with the EZ-10 Spin Column DNA Gel Extraction Kit (Bio Basic, Markham, Canada) with a final elution volume of $25 \mu \mathrm{l} .10 \mu \mathrm{l}$ of this size-selected microsatellite enriched DNA was ligated in plasmid vector with T4 DNA ligase (pGEM T-easy Vector System, Promega). The ligated plasmid vectors were then transformed into $\mathrm{DH} 5 \alpha$ competent $E$. coli cells with Z-Competent E. coli Transformation Kit (Zymo Research, Irvine, CA, USA). Plasmids of 48 positive clones were purified with EZ-10 Spin Column Plasmid DNA Kit (Bio Basic) and sequenced with ABI BigDye Terminator 3.1 kit (Applied Biosystems) on an ABI 3100 Genetic Analyzer (Applied Biosystems). Of the 18 sequences that contained $>10$ microsatellite repetitions, 6 had insufficient flanking regions or were sequence duplicates. For the remaining 12 sequences forward and reverse primers were manually designed on the microsatellite flanking regions. PCRs with the designed primers, fragment length detection and analysis for the evaluation of the loci were carried out as earlier described for the microsatellite loci from the related species.

After genotyping all 40 accessions of $S$. josikaea with all transferred and newly designed microsatellite markers, the exact match of multilocus genotypes and genotype probability for the two populations were calculated with GenAlEx 6.5 (Peakall and Smouse, 2012).

\section{Results and discussion}

\section{Transferability of microsatellite primers from the related} genera Olea and Ligustrum

Only one of the two Olea europaea and five out of the ten Ligustrum ovalifolium loci were amplified consistently for S. josikaea (Tab. 1). Two of these (Emo90 and Lig1 1) were monomorphic over all accessions. One of the remaining four primer pairs (Lig101) turned out to have an inconsistent banding pattern (i.e. multiple peaks in several samples). Two L. ovalifolium loci (Lig15, Lig21) proved to be variable in length, were easy to amplify and presented a consistent banding pattern (Tab. 2). The 14 alleles found in the two $S$. josikaea populations for $\operatorname{Lig} 15$ is only two less than what was found in $21 \mathrm{~L}$. ovalifolium samples by Kodoma et al. (2008). The number of alleles revealed for Lig21 in $S$. josikaea was lower compared to $L$. ovalifolium ( 7 versus 23 ) and in addition the allele lengths were shorter (171-187 versus 251-311). Both presume a significant sequence divergence at this locus between the two species.

\section{De novo microsatellite primer development}

Of the designed 12 primer pairs 3 had no product at all or gave smear and 9 produced clear bands on agarose gel. Of these 6 shared a single allele over all samples and 3 were variable. The sequences of the three variable loci were deposited in the NCBI GenBank (accession numbers are Syr4: KC540699; Syr5: KC540700; Syr9: KC540701). These newly designed markers are based on relatively long: 36,36 and $3+31+6$ microsatellite tandem repetitions (Tab. 2). While Syr 4 and Syr5 had no marked stuttering, Syr9 presented pronounced stutter bands to the extent that, at first glance, these were thought to hinder exact allele calling (Fig. 1). However the strange stuttering pat-

Tab. 1. List of tested Olea europaea and Ligustrum ovalifolium microsatellite loci and their features in amplification for Syringa josikaea

\begin{tabular}{|c|c|c|c|}
\hline & Amplification & Polymorphism & Consequent banding pattern \\
\hline \multicolumn{4}{|c|}{ Olea europaea } \\
\hline Emol3 & - & - & - \\
\hline Emo90 & + & - & - \\
\hline \multicolumn{4}{|c|}{ Ligustrum ovalifolium } \\
\hline Lig2 & - & - & - \\
\hline Lig8 & - & - & - \\
\hline Lig11 & + & - & - \\
\hline $\operatorname{Lig} 14$ & + & - & - \\
\hline $\operatorname{Lig} 15$ & + & + & + \\
\hline $\operatorname{Lig} 18$ & - & - & - \\
\hline $\operatorname{Lig} 20$ & - & - & - \\
\hline $\operatorname{Lig} 21$ & + & + & + \\
\hline $\operatorname{Lig} 22$ & - & - & - \\
\hline Lig101 & + & + & - \\
\hline
\end{tabular}

Amplification: success of PCR after optimization. Polymorphism: variability of the loci. Consequent banding pattern: always one or two putative allele bands appear with their sizes consequently repeating among samples. + means positive result, - means negative result 


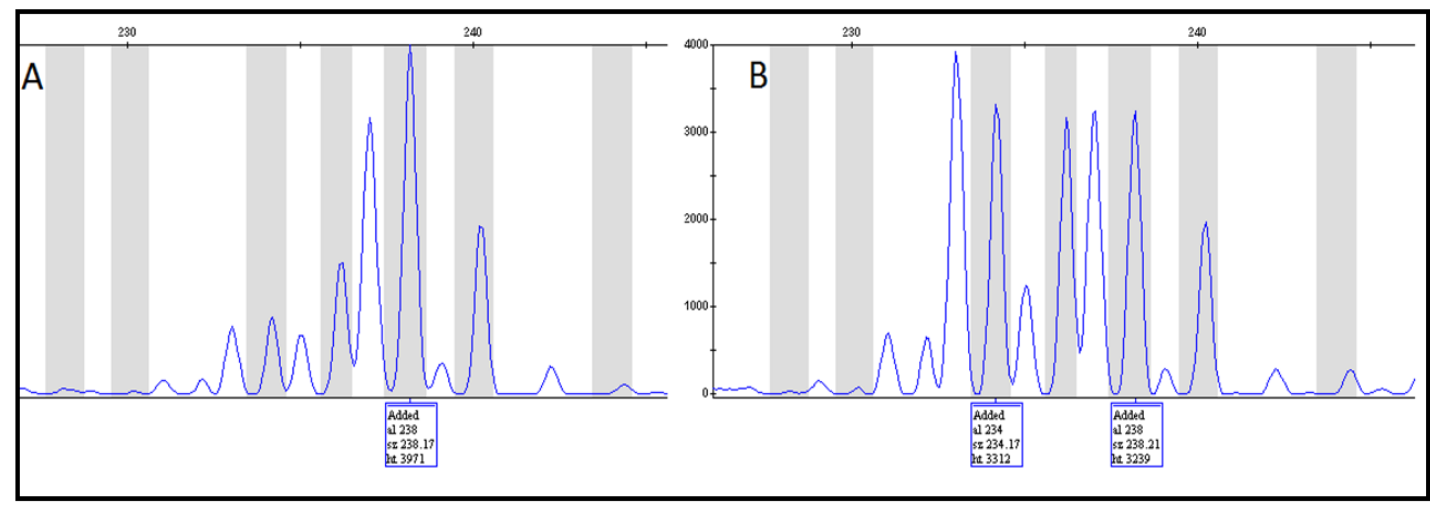

Fig. 1. View of two samples of Syr9 locus in GeneMapper v3.7

Peaks of the true alleles are marked, and are surrounded by stutter bands in a particular pattern. This stuttering pattern is consequent and allows easy identification of alleles even with only two base pair differences. Part A shows an individual homozygote for Syr9 with both alleles at 238 bp, part B shows a heterozygote sample with alleles at 234 and $238 \mathrm{bp}$.

tern was consistently present for all samples, and allows to distinguish easily even between alleles with only two base pair differences.

The number of alleles in the characterized five loci ranged from 7 to 21 with a total of 71 alleles in the two studied populations. This suggests a high resolution and information content of these loci. 39 multilocus genotypes were identified in the 40 samples of two $S$. josikaea populations. Only one recurrent genotype was found in two samples from neighboring plants from Pidpolozzya and we assume that these belonged to the same clone. This assumption is confirmed by the result of the DNA profile probability test, which shows that in this set of data the likelihood for the reoccurrence of this particular genotype just by chance would be $1.26 \times 10^{-8}$. Observed heterozygosity of the loci ranged from 0.4 to 1.0. Expected heterozygosity varied between 0.5731 and 0.9259 . Significant deviation from Hardy-Weinberg expectations was found in two occasions: for Syr9 from Remeți and for Lig21 from Pidpolozzya (Tab. 3).

Tab. 2. Characteristics of the loci successfully transferred and developed for $S$. josikaea

\begin{tabular}{|c|c|c|c|c|c|c|c|}
\hline $\begin{array}{l}\text { Locus } \\
\text { name }\end{array}$ & PCR primer sequence $\left(5^{\prime}-3^{\prime}\right)$ & repeat motif & $\mathrm{T}_{\mathrm{a}}\left({ }^{\circ} \mathrm{C}\right)$ & $\mathrm{N}$ & $\begin{array}{c}\text { Allele length } \\
\text { range (bp) }\end{array}$ & $\mathrm{N}_{\mathrm{A}}$ & $\mathrm{N}_{\mathrm{C}}$ \\
\hline \multirow[t]{2}{*}{$\operatorname{Lig} 15$} & F: AGT CTC AGG CAG ATT CAA AT & $(\mathrm{CT})_{25}(\mathrm{CA})_{10}^{*}$ & 52 & 40 & $167-205$ & 14 & 10 \\
\hline & R: GAG AAT TAG TCA AAT CAA ATC & & & & & & \\
\hline \multirow[t]{2}{*}{$\operatorname{Lig} 21$} & F: GGC TAC AAC CCA CCT TAA ATA C & $(\mathrm{AG})_{25}{ }^{*}$ & 52 & 40 & $171-187$ & 7 & 25 \\
\hline & R: TTA CGC ACG GGT TGT GGC TA & & & & & & \\
\hline \multirow[t]{2}{*}{ Syr4 } & F: GGG TGT GTC CAA AAA TTC TG & $(\mathrm{AG})_{36}$ & 52 & 40 & $201-240$ & 17 & 21 \\
\hline & R: TCG AAC CAT TGC TTA TTT CAA C & & & & & & \\
\hline \multirow[t]{2}{*}{ Syr 5} & F: TTG GTC TAA TGC TGG ACA CAA & $(\mathrm{GA})_{36}$ & 52 & 40 & $152-212$ & 21 & 34 \\
\hline & R: CAA TGC GGG CAA ATA TTC AC & & & & & & \\
\hline \multirow[t]{2}{*}{ Syr9 } & F: GGA AAT CTG CTT GTT GAT ACC & $(\mathrm{TGC})_{3}(\mathrm{TC})_{31}(\mathrm{TG})_{6}$ & 52 & 40 & $234-272$ & 12 & 17 \\
\hline & R: CAC ACA CAC ACA GAG AGA GAG & & & & & & \\
\hline
\end{tabular}

F, forward primer; R, reverse primer, $\mathrm{T}_{\mathrm{a}}$, annealing temperature; $\mathrm{N}$, number of screened individuals; $\mathrm{N}_{\mathrm{A}}$, number of found alleles; $\mathrm{N}_{\mathrm{G}}$, number of found genotypes. ${ }^{*}$ These repeat motifs were found in L. ovalifolium, no data is available for $S$. josikaea

Tab. 3. Genetic diversity characteristics of the loci in the two populations

\begin{tabular}{cccccccccc}
\hline \multirow{2}{*}{ Locus name } & \multicolumn{4}{c}{ Remeți } & \multicolumn{4}{c}{ Pidpolozzya } \\
\cline { 2 - 10 } & $\mathrm{H}_{\mathrm{O}}$ & $\mathrm{H}_{\mathrm{F}}$ & $\mathrm{p} \mathrm{HWE}$ & $\mathrm{F}_{\text {IS }}$ & $\mathrm{H}_{\mathrm{O}}$ & $\mathrm{H}_{\mathrm{E}}$ & $\mathrm{pHWE}$ & $\mathrm{F}_{\text {IS }}$ \\
\hline Lig15 & 0.9000 & 0.8385 & 0.5656 & -0.0615 & 0.6500 & 0.8231 & 0.0867 & 0.2103 \\
Lig21 & 0.4000 & 0.5731 & 0.0517 & 0.1731 & 0.5500 & 0.7051 & $\mathbf{0 . 0 1 4 4}$ & 0.22 \\
Syr4 & 1.0000 & 0.8872 & 0.1088 & -0.1128 & 0.6500 & 0.7282 & 0.1214 & 0.1074 \\
Syr5 & 0.9500 & 0.9039 & 0.2242 & -0.0462 & 0.7500 & 0.9295 & 0.0547 & 0.1931 \\
Syr9 & 0.5500 & 0.8705 & $<\mathbf{0 . 0 0 1}$ & 0.3205 & 0.5000 & 0.6500 & 0.121 & 0.2308 \\
\hline
\end{tabular}

$\mathrm{H}_{\mathrm{O}}$, observed heterozygosity, $\mathrm{H}_{\mathrm{E}}$, expected heterozygosity; $\mathrm{p} \mathrm{HWE}$, probability of deviation from Hardy-Weinberg-equilibrium, $<0.05$ significant values indicated in bold; $\mathrm{F}_{\mathrm{IS}}$, inbreeding coefficient 


\section{Conclusions}

The five microsatellite markers characterized for $S$. josikaea were easy to amplify and score. Moreover, as allele lengths of the loci overlap and each primer pair can be used at the same annealing temperature, a single-tube multiplex PCR may be applicable for these primers. The high rate of variability of these markers should make them valuable tools in population genetic studies for conservation planning. Furthermore, they may be used in breeding programs for paternity tests and surveys on genetic relatedness of hybrids and cultivars of $S$. josikaea.

\section{Acknowledgment}

The grants TÁMOP-4.2.1./B-09/01/KMR/20100005 and TÁMOP-4.2.2./B-10/1-2010-0023 financially supported this study. The authors are grateful for the assistance in the laboratory work for Zsuzsanna György, Bernadett Szikriszt and Ádám Gutermuth. The guidance for sample collection is acknowledged for Erzsébet Kohut, Anna Mária Csergő and Tamás Pócs. Simon Hutchinson is thanked for checking the English text.

\section{References}

Bloor PA, Barker FS, Watts PC, Noyes HA, Kemp SJ (2001). Microsatellite libraries by enrichment, Version 1.0. http:// www.genomics.liv.ac.uk/animal/MICROSAT.PDF Online accessed: 14th February 2013.

de la Rosa R, James CM, Tobutt KR (2002). Isolation and characterization of polymorphic microsatellites in olive (Olea europaea L.) and their transferability to other genera in the Oleaceae. Mol Ecol Notes 2:265-267.

Dihoru G, Negrean G (2009). Syringa josikaea, 532-533 p. In: Dihoru G, Negrean G (Eds.). Cartea rosie a plantelor vasculare din Romania. (Red book of vascular plants of Romania). Academia Romana Institutul de Biologie Bucuresti, Bucuresti.

Excoffier L, Lischer HEL (2010). Arlequin suite ver 3.5: A new series of programs to perform population genetics analyses under Linux and Windows. Mol Ecol Resour 10:564-567.

Fiala JL (2008). Lilacs: a gardeners encyclopedia. 2nd ed, rev. and updated by Freek Vrgutman. Timber Press, Portland London.

Frankham R, Ballou JD, Briscoe DA (2002). An Introduction to Conservation Genetics. Cambridge University Press, Cambridge.

Guo SW, Thompson EA (1992). Performing the exact test of Hardy-Weinberg proportion for multiple alleles. Biometrics 48:361-372.
305

HuiRong L, WanChun G, Jun M (2009). Determining genetic diversity of natural population of Syringa oblata using allozyme markers. Journal of Beijing Forestry University 31(5):84-89.

Kochieva EZ, Ryzhova NN, Molkanova OI, Kudryavtsev AM, Upelniek VP, Okuneva IB (2004). The genus Syringa: molecular markers of species and cultivars. Russ J Genet 40(1):30-32.

Kodama K, Yamada T, Maki M (2008). Development and characterization of 10 microsatellite markers for the semi-evergreen tree species, Ligustrum ovalifolium (Oleaceae). Mol Ecol Resour 8:1008-1010.

Lendvay B, Kohut E, Höhn M (in press). Historical and recent distribution of Syringa josikaea Jacq. fil. ex Rchb., ecological and conservational evaluation of the remnant populations. Kanitzia 18.

Li J, Alexander JH, Zhang D (2002). Paraphyletic Syringa (Oleaceae): Evidence from sequences of nuclear ribosomal DNA ITS and ETS regions. Syst Bot 27(3):592-597.

Li J, Goldman-Huertas B, DeYoung J, Alexander J III (2012). Phylogenetics and diversification of Syringa inferred from nuclear and plastid DNA sequences. Castanea 77(1):82-88.

Marsolais JV, Pringle JS, White BN (1993). Assessment of random amplified polymorphic DNA (RAPD) as genetic markers for determining the origin of interspecific lilac hybrids. Taxon 42:531-537.

Melnikova NV, Borhert EV, Martynov SP, Okuneva IB, Molkanova OI, Upelniek VP, Kudryavtsev AM (2009). Molecular genetic marker-based approaches to the verification of lilac Syringa vulgaris L. in vitro germplasm collections. Russ J Genet 45(1):85-90.

Peakall R, Smouse PE (2012). GenAlEx 6.5: genetic analysis in Excel. Population genetic software for teaching and researchan update. Bioinformatics 28:2537-2539.

Powell W, Machray GC, Provan J (1996). Polymorphism revealed by simple sequence repeats. Trends Plant Sci $1(7): 215-222$

Rzepka-Plevneš D, Smolik M, Tańska K (2006). Genetic similarity of chosen Syringa species determined by the ISSRPCR technique. Dendrobiology 56:61-67.

Schuelke M (2000). An economic method for the fluorescent labeling of PCR fragments. Nat Biotechnol 18:233-234.

Xinlu C, Zhenfeng C, Jing H (1999). Using random amplified polymorphic DNA (RAPD) markers for lilac genetic analysis and classification in lilac cultivars. Acta Bot BorealiOccident Sin 19(2):169-176.

Zane L, Bargelloni L, Patarnello T (2002). Strategies for microsatellite isolation: a review. Mol Ecol 11:1-16. 